\title{
A model of perception of ambient learning environment, perception of online learning environment and learning environment satisfaction: \\ A survey instrument
}

\begin{abstract}
This research paper introduced a survey instrument for evaluating learning environment satisfaction from home ambient environment experience and online learning environment experience. The survey questions examined a range of ambient environment factors together with scales extracted from online learning environment survey (OLLES) (Clayton, 2007) to systematically measure learning environment perception. The questionnaire was then tested in a field study. Exploratory and confirmatory factor analyses revealed a six-factor model of students' satisfaction with learning environment including ambient environment, student-student interaction, student-interface relationships, student-tutor relationships, student-content relationships, and student reflection activities. Structural equation modeling explained relationship among perception of ambient learning environment, perception of online learning environment and learning environment satisfaction. The development and field test of this survey tool enable evaluations of online learning environment within consideration of ambient environment, as well as support learning environment design and management.
\end{abstract}

Keywords

Ambient environment, online learning environment, learning environment satisfaction, survey, factor analysis, structural equation modeling 


\section{INTRODUCTION}

\section{Online Learning}

The three terms, e-Learning, distance learning and online learning, are overlapped with nuanced differences. Distance learning lies more on time and place (Newby et al., 2000) while e-learning is more on tools and technology. Nichols (2003) defined E-Learning as strictly accessible using tools that are related to web. However, Ellis (2004) disagreed with this definition and suggested other technologies such as CD-ROM, TV and video should also be included. Among the three definitions, online learning can be most difficult to define (Moore et al., 2011). Online learning is described by most authors as access to learning experiences via the use of some technology (Moore et al., 2011). Some researchers (Triacca et al., 2004) classified e-Learning as a type of online learning.

This study uses "online learning" as 1) it is a more general term comparing with e-Learning and distance learning, 2) it is more focusing on experience and less on either time, place or technology. Also, these three terms are interchanged when describing the learning environment (Moore et al., 2011).

\section{Learning Environment}

Learning environment refers to the diverse physical locations, contexts, and cultures in which students learn (Eglossary, 2016). Researchers pointed out that this term, however, is regularly used to refer to the social, psychological, or conceptual environment rather than to the physical learning environment or space (Cleveland 2009). 'Learning environments research' sometimes suffers from a lack of clarity about what an environment is. (Ellis, 2016)

Online learning environment usually refers to virtual environment where learning happens rather than physical environment. Inspired from Kurt Lewin's famous equation $B=f(p, e)$, where $\mathrm{B}=$ behavior, $\mathrm{p}=$ person, and e=environment, Clayton $(2004,2007)$ summarized five categories of online learning activity and created Online learning environment survey (OLLES) accordingly to measure online learning environment. These five categories are developed from four relationships between students and learning environment from formal studies (Haynes, 2002) and added "student reflection" to strengthen the importance of investigating how individual reflects on his learning environment. These five categorizes are:

1. Student - Interface Interaction (What are the features of the interface created that enhance / inhibit student learning and navigation?)

2. Student - Student Relationships (How, why and when students communicate with each other and what is the nature of this communication?)

3. Student - Tutor Relationships (How, why and when students communicate with their tutor and what is the nature of this communication?)

4. Student-Media Interaction (How is the student engaged with digitally stored information and how do they relate to the information presented?)

5. Student Reflection Activities. (How are students encouraged to reflect on their learning, are they satisfied with the environment and how do they relate to the environment created?) 
However, her study may lack the consideration of the effect of physical environment on students' learning experience. If we use an ecological perspective to take a broader definition of online learning environment, then some more category should be included. From the knowledge as far as we know, there is no research on combine the physical environment with online environment together and take a systematic measurement. To investigate the how physical environment, influence online learning process, this study will add another category to evaluate the learning environment.

From a brief review of physical learning environment, there are two different attributes: ambient attributes and spatial attributes. Ambient attributes include temperature, air quality, acoustics and lighting (Earthman, 2014; Lackney, 2000; Shaughnessy, 2006; Shukuya, 2012). Spatial attributes include size, shape, furniture, seating arrangement, color selection and nature accessibility (Safer et al., 2005; Niemeyer, 2003; Veltri et al., 2006; The L-Shaped Classroom, 2007; Papadatos, 1973). This study mainly focuses on ambient environment attributes and will add the sixth categories for measuring:

6. Student-Ambient Environment. (How ambient environment attributes in physical environment affect their learning experience?)

\section{Research Questions}

Educational institutions closed their physical facilities in China because of COVID-19. Students are required to stay at home and study online by watching videos created by their instructors. This event provides an opportunity to investigate students learning environment and understand the following two research questions in this study:

1. How valid and reliable of the new survey adding ambient environment category to measure learning environment systematically?

2. What is the relationship among perception of ambient learning environment, perception of online learning environment and overall learning environment satisfaction?

\section{HYPOTHESES}

From the review of online learning environment and physical learning environment above, we may test the following hypotheses based on data collected using the new survey tool:

H1: The measures of perception of learning environment can be reduced to six factors that respectively represent Student - Interface Interaction, Student - Student Relationships, Student - Tutor Relationships, Student - Media Interaction, Student Reflection Activities and Student - Ambient Environment.

$\mathrm{H} 2$ : Both perception of ambient learning environment and perception of online learning environment can be related to overall learning environment satisfaction. 


\section{METHODS}

\section{Sites and Participants}

Field studies were carried from the help from four local middle schools in Hangzhou, China. Altogether, 523 students from 16 classes taught by 8 instructors were studied, with 8 classes in Grade 7 and 8 classes in Grade 8. Each class is similar in size and each grade learns similar content-English. The age of students in Grade 7 is from 13-14 while in Grade is from 14-15.

Since Spring semester begins (Late February), all students are required to stay at homes studying online video made by their instructors. Some videos are synchronous, and some are asynchronous. Students watch the video by multiple facilities like laptops, phones, pads etc.

They also submit homework, ask and answer questions, and communicate with instructors using online platforms. Every student has his own studying desk at his home but not every has his own room to study.

The survey is conducted on early April, till then students already studied at home for about two months. Questionnaires are distributed by instructors to their own classes using an online survey system named "Wenjuanxing". All students complete and submit the questionnaires by phones. Instructors then sent the results to the author.

Table 1: Participant characteristics

\begin{tabular}{|l|l|l|l|l|}
\hline $\mathrm{N}$ & \multicolumn{2}{|l|}{ Grade 7 } & Grade 8 & \multicolumn{2}{l|}{} \\
\hline \multirow{2}{*}{523} & Male & Female & Male & Female \\
\cline { 2 - 5 } & 142 & 129 & 127 & 125 \\
\hline
\end{tabular}

\section{Measures}

Participants are invited to fill out a forty-question, web-based "Learning Environment Evaluation Questionnaire" consisting four sections: demographic information, home learning environment, online learning environment and general learning environment. This paper only covers part of questions in the questionnaire. The questionnaire is translated into Chinses.

\section{Ambient learning environment}

Perception of ambient learning environment is intended to be measured in the second section: home learning environment. This section has 11 questions and 4 are on ambient learning environment. Questions are made based on literature reviews on what and how ambient attributes affect learning behavior. Four questions are created to measure perceived ambient environment comfort on temperature, lightning, acoustics condition and air quality. Sample question is like 
"How do you feel the temperature when you study?". Each question is given a choice from one to seven corresponding least comfortable to most comfortable.

\section{Online learning environment}

Perception of online learning environment is intended to be measured in the third section: online learning environment. This section has 24 questions and is extracted and modified from 35-item version of the OLLES created by Clayton (2007). The validation of the OLLES has been proved by her in studies in 2011. I removed some questions as they do not fit the context of this study. After adoption, this part will measure five subscales. Each question is also given a choice from one to seven corresponding never to always.

Table 1: Matrix of questions, scales in the questionnaire covered in this paper

\begin{tabular}{|l|l|l|l|}
\hline Categorizes & Code & Questions & Sample Question \\
\hline $\begin{array}{l}\text { Student - Ambient } \\
\text { Relationships }\end{array}$ & SA & Q6, Q7, Q8, Q9 & $\begin{array}{l}\text { Q5: How do you feel the temperature when } \\
\text { you study? }\end{array}$ \\
\hline $\begin{array}{l}\text { Student - Interface } \\
\text { Interaction }\end{array}$ & SI & $\begin{array}{l}\text { Q19, Q20, Q21, } \\
\text { Q22, Q23 }\end{array}$ & $\begin{array}{l}\text { Q21: I am confident in using the WWW to } \\
\text { search for information. }\end{array}$ \\
\hline $\begin{array}{l}\text { Student - Student } \\
\text { Relationships }\end{array}$ & SS & $\begin{array}{l}\text { Q14, Q15, Q16, } \\
\text { Q17, Q18 }\end{array}$ & $\begin{array}{l}\text { Q16: I often ask other students for help in } \\
\text { assignments we are doing }\end{array}$ \\
\hline $\begin{array}{l}\text { Student - Tutor } \\
\text { Relationships }\end{array}$ & ST & $\begin{array}{l}\text { Q25, Q25, Q26, } \\
\text { Q27, Q28 }\end{array}$ & $\begin{array}{l}\text { Q25: The tutor encourages my } \\
\text { participation. }\end{array}$ \\
\hline $\begin{array}{l}\text { Student - Media } \\
\text { Interaction }\end{array}$ & SM & $\begin{array}{l}\text { Q29, Q30, Q31, } \\
\text { Q32, Q33 }\end{array}$ & Q29: The video is clear. \\
\hline $\begin{array}{l}\text { Student Reflection } \\
\text { Activities }\end{array}$ & SR & $\begin{array}{l}\text { Q34, Q35, Q36, } \\
\text { Q37, }\end{array}$ & Q34: I find online learning is exciting. \\
\hline $\begin{array}{l}\text { General Environment } \\
\text { Satisfaction }\end{array}$ & & Q40 & $\begin{array}{l}\text { Q40: Generally, I am satisfied with the } \\
\text { learning environment. }\end{array}$ \\
\hline
\end{tabular}

\section{Analysis}

In this study, Hypothesis 1 was tested using explorative factor analysis and confirmatory factor analysis. Structural equation modeling was carried out to test Hypothesis 2. For testing H1, the data set was randomly split into two independent subsets for explorative factor analysis and confirmatory factor analysis respectively. $\mathrm{H} 2$ used the full dataset. All analysis calculations are conducted using R. Psych (Revelle, W. \& Revelle, 2015) is used for explorative factor analysis and calculating Cronbach alpha; Lavaan (Rosseel, 2012) is used for confirmatory factor analysis and structural equation modeling. 


\section{RESULTS}

\section{Descriptive statistics}

There is no missing observation and no univariate outlier identified. The mean, standard deviation, skewness and kurtosis of all items in this study are shown in Table 3. Each variable has 7 levels and is treated as continues number from 1 to 7 .

Table 3: Descriptive statistics of all variables, $\mathrm{N}=523$

\begin{tabular}{|l|r|r|r|r|}
\hline Variable & Mean & StDev & Skewness & \multicolumn{1}{|c|}{ Kurtosis } \\
\hline Q6 & 5.361377 & 1.232308 & -0.52627 & -0.40027 \\
\hline Q7 & 4.910134 & 1.380472 & -0.31429 & -0.56588 \\
\hline Q8 & 5.527725 & 1.250554 & -0.93982 & 0.792081 \\
\hline Q9 & 5.50478 & 1.189625 & -0.59054 & -0.4314 \\
\hline Q14 & 6.063098 & 1.058552 & -1.76005 & 4.450556 \\
\hline Q15 & 3.929254 & 1.382971 & 0.022466 & 0.322123 \\
\hline Q16 & 2.755258 & 1.365049 & 0.243427 & -0.6488 \\
\hline Q17 & 2.583174 & 1.485003 & 0.588157 & -0.35716 \\
\hline Q18 & 3.18738 & 1.472374 & 0.160789 & -0.26531 \\
\hline Q19 & 3.17782 & 1.434698 & 0.110636 & -0.30981 \\
\hline Q20 & 3.564054 & 1.609719 & 0.118415 & -0.43215 \\
\hline Q21 & 4.657744 & 1.661911 & -0.34395 & -0.39522 \\
\hline Q22 & 4.571702 & 1.85182 & -0.20802 & -0.94569 \\
\hline Q23 & 5.015296 & 1.715312 & -0.53967 & -0.45542 \\
\hline Q24 & 5.097514 & 1.572042 & -0.46798 & -0.2399 \\
\hline Q25 & 5.629063 & 1.34338 & -0.8147 & 0.382605 \\
\hline Q26 & 5.726577 & 1.320267 & -0.8258 & 0.279148 \\
\hline Q27 & 5.634799 & 1.405549 & -0.79855 & 0.098364 \\
\hline Q28 & 5.669216 & 1.253176 & -0.86911 & 0.870838 \\
\hline Q29 & 5.632887 & 1.209409 & -0.58717 & -0.02086 \\
\hline Q30 & 5.674952 & 1.367901 & -0.89462 & 0.53327 \\
\hline Q31 & 5.625239 & 1.219688 & -0.49045 & -0.32198 \\
\hline Q32 & 5.684512 & 1.230943 & -0.58431 & -0.12664 \\
\hline Q33 & 4.904398 & 1.576419 & -0.40192 & -0.28291 \\
\hline Q34 & 5.544933 & 1.347407 & -0.71669 & 0.312955 \\
\hline Q35 & 4.988528 & 1.393699 & -0.25505 & -0.19007 \\
\hline Q36 & 4.248566 & 1.689321 & -0.01146 & -0.59674 \\
\hline Q37 & 3.814532 & 1.780594 & 0.198877 & -0.61884 \\
\hline Q40 & 5.466539 & 1.320458 & -0.6353 & 0.216443 \\
\hline
\end{tabular}




\section{Hypothesis One}

\section{Descriptive statistics}

The full data was first randomly split into 2 subsets with 261 observations in subset 1 and 262 observations in subset 2. The Mean, Standard deviation and skewness of these two subsets are similar as is shown in Table 4.

Table 4: Descriptive statistics of variables used in H1, Subset 1, N=261; Subset 2, N = 262

\begin{tabular}{|c|c|c|c|c|c|c|}
\hline Variable & $\begin{array}{l}\text { Mean } \\
\text { (Subset1) }\end{array}$ & $\begin{array}{l}\text { StDev } \\
\text { (Subset1) }\end{array}$ & $\begin{array}{l}\text { Skewness } \\
\text { (Subset1) }\end{array}$ & $\begin{array}{l}\text { Mean } \\
\text { (Subset2) }\end{array}$ & $\begin{array}{l}\text { StDev } \\
\text { (Subset2) }\end{array}$ & $\begin{array}{l}\text { Skewness } \\
\text { (Subset2) }\end{array}$ \\
\hline Q6 & 5.344828 & 1.254171 & -0.53948 & 5277862 & 1.212312 & -0.50549 \\
\hline Q7 & .927203 & 1.315027 & -0.24044 & 4.89313 & .445044 & -0.36043 \\
\hline Q8 & 528736 & 1.238849 & -0.82123 & 5.526718 & .264476 & -1.0 \\
\hline Q9 & 528736 & 1.161952 & 36 & 5.480 & 218 & 98 \\
\hline Q12 & 310345 & 1.291782 & & 5.190 & .536 & -0.6 \\
\hline Q14 & 969349 & 1.139762 & -1.6 & 6.156489 & .964075 & -1.7 \\
\hline Q15 & 3.931034 & 1.385028 & 0.05 & 3.927 & 383 & -0.0 \\
\hline Q16 & 827586 & 1.351981 & 0.1 & 2.683 & .376 & 0.3 \\
\hline Q17 & 01 & 1.517537 & & 2.56 & 454 & 54 \\
\hline Q18 & 3218 & 1.4657 & 0.16 & 39 & & \\
\hline Q19 & 3.180 & 1.406764 & 0.10 & 3.17 & 46 & 27 \\
\hline $\mathrm{Q} 20$ & 3.628352 & 1.620719 & 0.17 & 3.5 & .599 & 793 \\
\hline $\mathrm{Q} 21$ & 789272 & 1.558364 & -0.2 & 4.526 & 752189 & -0.3 \\
\hline $\mathrm{Q} 22$ & & & & & 77 & \\
\hline $\mathrm{Q} 23$ & 54 & 1.605032 & 51 & 1 & 6 & \\
\hline $\mathrm{Q} 24$ & 4.927203 & 1.602422 & -0.4 & 5.267 & 1.525389 & -0.4 \\
\hline $\mathrm{Q} 25$ & 578544 & 1.332493 & -0.7 & 5.679 & 1.354 & -0.8 \\
\hline Q26 & 5.747 & 1.2236 & & & 04 & 73 \\
\hline $\mathrm{Q} 27$ & 5.62069 & 1.3206 & & 5.648 & 46 & \\
\hline Q28 & .624521 & 1.194866 & -0.6 & 5.71 & 57 & -1.0 \\
\hline Q29 & 547893 & 1.216317 & -0.4 & 5.717 & 1.198817 & -0.7 \\
\hline Q30 & 5.605364 & 1.330634 & -0.5 & 5.744275 & .403 & -1.1 \\
\hline Q31 & 5.605364 & 1.193496 & -0.42481 & 5.645038 & 1.247202 & -0.5488 \\
\hline Q32 & 5.662 & 1.250122 & -0.5 & 5.70 & 1.213 & -0.6 \\
\hline Q33 & 4.923372 & 1.544802 & -0.3 & 4.885496 & 1.610032 & -0.4 \\
\hline Q34 & 5.517241 & 1.299663 & -0.63981 & 5.572519 & 1.395288 & -0.78109 \\
\hline $\mathrm{Q} 35$ & 5.12214 & 1.341641 & -0.27606 & 4.977099 & 1.446177 & -0.23282 \\
\hline Q36 & 4.287356 & 1.607014 & 0.005514 & 4.209924 & 1.769748 & -0.01255 \\
\hline Q37 & 3.850575 & 1.737784 & 0.172186 & 3.778626 & 1.824861 & 0.226151 \\
\hline
\end{tabular}




\section{Explorative factor analysis}

Subset $1(\mathrm{~N}=261)$ was used for explorative factor analysis to identify latent variables of perceptions of learning environment. 28 items were analyzed. The Pearson correlation of the 28 items disproved the existence of multicollinearity. The largest correlation coefficient observed is 0.81 , occurring between Q36 "I feel the online learning can enhance the classroom normal leaning" and Q37 "I feel I learn more online".

The Scree plot with parallel analysis suggested the number of factors is six (Fig 1) which is a logic fit to the scales in H1. The cumulative variance of all 6 factors is $57 \%$. The proximal rotation was used to identify the loading of each item. The six factors are labeled Student Interface Interaction (SA), Student - Student Relationships (SS), Student - Tutor Relationships (ST), Student - Media Interaction (SM), Student Reflection Activities (SR) and Student Ambient Environment (SA). Six items with loadings smaller than 0.5 are excluded. Loading of each item is reported in Table 4. Cronbach alpha of each factor is also calculated and reported in Table 5.

Scree plots with parallel analysis

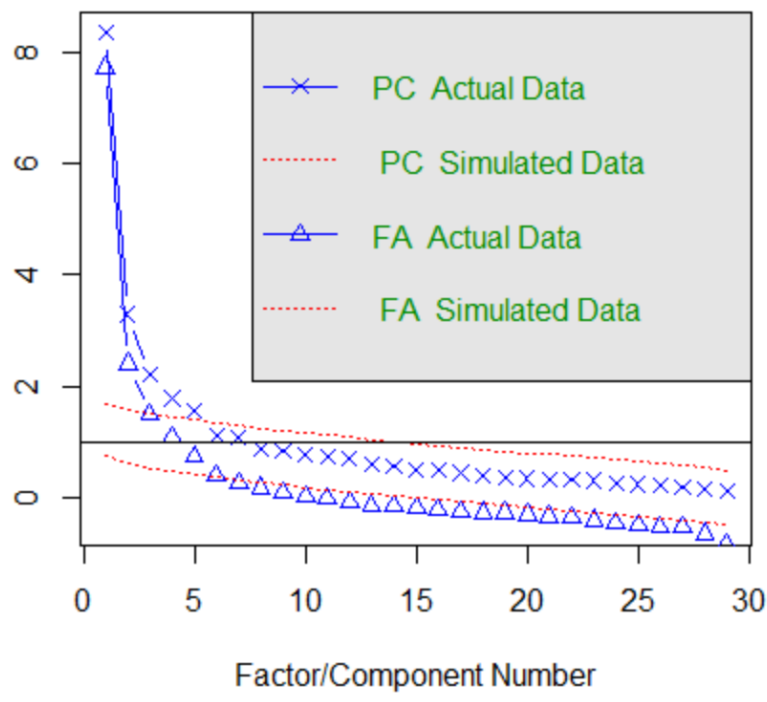

Fig 1: Scree plot with parallel analysis of learning environment survey 
Table 5:

Perception of learning environment items and rotated six-factor exploratory factor analysis results, $\mathrm{N}=261$

\begin{tabular}{|c|c|c|c|c|c|c|}
\hline Questions & $\begin{array}{l}\text { Factor\#1: } \\
\text { SA }\end{array}$ & $\begin{array}{l}\text { Factor\#2: } \\
\text { SS }\end{array}$ & $\begin{array}{l}\text { Factor\#3: } \\
\text { SI }\end{array}$ & $\begin{array}{l}\text { Factor\#4: } \\
\text { ST }\end{array}$ & $\begin{array}{l}\text { Factor\#5: } \\
\text { SM }\end{array}$ & $\begin{array}{l}\text { Factor\#6: } \\
\text { SR }\end{array}$ \\
\hline Q6 & 0.72 & & & & & \\
\hline Q7 & 0.67 & & & & & \\
\hline$Q 8$ & 0.8 & & & & & \\
\hline Q9 & 0.85 & & & & & \\
\hline Q16 & & 0.74 & & & & \\
\hline Q17 & & 0.77 & & & & \\
\hline Q18 & & 0.85 & & & & \\
\hline Q19 & & 0.88 & & & & \\
\hline Q21 & & & 0.51 & & & \\
\hline Q22 & & & 0.69 & & & \\
\hline Q23 & & & 0.79 & & & \\
\hline Q24 & & & & 0.57 & & \\
\hline Q25 & & & & 0.72 & & \\
\hline Q26 & & & & 0.73 & & \\
\hline Q29 & & & & & 0.73 & \\
\hline Q30 & & & & & 0.68 & \\
\hline Q31 & & & & & 0.98 & \\
\hline Q32 & & & & & 0.89 & \\
\hline Q33 & & & & & & 0.52 \\
\hline Q36 & & & & & & 0.99 \\
\hline Q37 & & & & & & 0.96 \\
\hline $\begin{array}{l}\text { \% Var } \\
\text { explained }\end{array}$ & 10.2 & 10.5 & 5.8 & 6.8 & 13.0 & 8.5 \\
\hline $\begin{array}{l}\text { Cronbach's } \\
\text { alpha }\end{array}$ & 0.81 & 0.87 & 0.68 & 0.78 & 0.82 & 0.81 \\
\hline
\end{tabular}

\section{Confirmative factor analysis}

Subset $2(\mathrm{~N}=262)$ was used for confirmatory factor analysis, which was conducted based on the six-factor model from exploratory factor analysis. The model (Model 1) consisted of 21 observed variables with six latent variables (factors). Each observed variable was hypothesized to load on one single factor, with 4 variables loading on SA, 4 variables loading on SS, 3 variables loading on SI, 3 variables loading on ST, 4 variables loading on SM and 3 variables loading on SR. The 6 factors were hypothesized to be correlated. In this model, there was no correlation among the measurement error variables. Overall, Model 1 contained maximum likelihood estimations of 21 factor loadings, 15 factor variances and 21 measurement error variances. 
Results of the CFA analysis indicated a marginal fit between the model and the data (Table 6: Model 1). All the factor loadings were statistically significant. Modification indices suggested adding covariance between the following measurement error variables: E16 and E17, E18 ad E19, E25 and E26, E36 and E37. Model 2 was estimated accordingly (Figure 2), and the results from the CFA showed a better model fit (Table 6: Model 2). Thus Model 2 is suggested to be the final model of factor structure for the perception of learning environment items. Table 7 shows the covariance coefficients between latent variables in Model 2.

Table 6: Fit statistics of the CFA

\begin{tabular}{|l|l|l|l|l|l|l|}
\hline & Chisq & $\begin{array}{l}\text { Chisq/df } \\
<3\end{array}$ & $\begin{array}{l}\text { GFI } \\
>0.9\end{array}$ & $\begin{array}{l}\text { NFI } \\
>0.9\end{array}$ & $\begin{array}{l}\text { CFI } \\
>0.9\end{array}$ & $\begin{array}{l}\text { RMSEA } \\
<0.1\end{array}$ \\
\hline Model 1 & 365.8 & 2.49 & 0.89 & 0.89 & 0.94 & 0.07 \\
\hline Model 2 & 271.5 & 1.60 & 0.91 & 0.92 & 0.97 & 0.05 \\
\hline
\end{tabular}



Fig 2: CFA Model 2 with standardized estimates $(\mathrm{N}=262)$

Table 7: Covariance coefficients between latent variables in Model 2

\begin{tabular}{|l|l|l|l|l|l|l|}
\hline & SA & SS & SI & ST & SM & SR \\
\hline SA & 1 & 0.14 & 0.49 & 0.52 & 0.44 & 0.40 \\
\hline SS & & 1 & 0.05 & 0.19 & 0.04 & 0.25 \\
\hline SI & & & 1 & 0.59 & 0.56 & 0.55 \\
\hline ST & & & & 1 & 0.90 & 0.63 \\
\hline SM & & & & & 1 & 0.69 \\
\hline SR & & & & & & 1 \\
\hline
\end{tabular}




\section{Hypothesis Two}

\section{Descriptive statistics}

The Mean, Standard deviation and skewness of 523 observations used in H2 are shown in Table 8. The mean score of each subscale of perception of online environment is calculated coded as SS, SI, ST, SM and SR.

Table 8: Descriptive statistics of variables used in $\mathrm{H} 2, \mathrm{~N}=523$

\begin{tabular}{|l|r|l|r|r|}
\hline Variable & \multicolumn{1}{|l|}{ Mean } & StDev & Skewness & \multicolumn{1}{l|}{ Kurtosis } \\
\hline Q6 & 5.361377 & 1.232308 & -0.52627 & -0.40027 \\
\hline Q7 & 4.910134 & 1.380472 & -0.31429 & -0.56588 \\
\hline Q8 & 5.527725 & 1.250554 & -0.93982 & 0.792081 \\
\hline Q9 & 5.50478 & 1.189625 & -0.59054 & -0.4314 \\
\hline SS & 2.925908 & 1.219016 & 0.198164 & -0.19328 \\
\hline SI & 4.748247 & 1.375504 & -0.30036 & -0.15054 \\
\hline ST & 5.484385 & 1.188637 & -0.5054 & -0.22744 \\
\hline SM & 5.654398 & 1.072644 & -0.40873 & -0.52023 \\
\hline SR & 4.322498 & 1.488029 & -0.01648 & -0.38198 \\
\hline Q40 & 5.466539 & 1.320458 & -0.6353 & 0.216443 \\
\hline
\end{tabular}

\section{Structural equation modeling}

In order to test $\mathrm{H} 2$, a CFA was conducted followed by a hypothesized model tested using structural equation modeling.

The model (Model 3) consisted of 9 observed variables with 2 latent variables (factors). Each observed variable was hypothesized to load on one single factor, with 4 variables loading on Ambient_Env and 5 variables loading on Online_Env. The 2 factors were hypothesized to be correlated. In this model, there was no correlation among the measurement error variables. Results of the CFA analysis indicated a marginal fit between the model and the data (Table 9: Model 3). All the factor loadings were statistically significant. Modification indices suggested deleting SS and adding covariance between the following measurement error variables: SM and ST, Q6 and Q7, Q8 and Q9. Model 4 was estimated accordingly and the results from the CFA showed a better model fit (Table 9: Model 4). Thus Model 4 is suggested to be the final model of SEM analysis. Fig 3 shows the final the result of SEM model. In the model, Ambient_Envi indicates perception of ambient environment measured by Q6, Q7, Q8, Q9; Online_Env indicates perception of online environment measured by SI, ST, SM, SR; Satisfaction indicates learning environment satisfaction measured by Q40. 
Table 9: Fit statistics of the CFA, $N=523$

\begin{tabular}{|l|l|l|l|l|l|l|}
\hline & Chisq & $\begin{array}{l}\text { Chisq/df } \\
<3\end{array}$ & $\begin{array}{l}\text { GFI } \\
>0.9\end{array}$ & $\begin{array}{l}\text { NFI } \\
>0.9\end{array}$ & $\begin{array}{l}\text { CFI } \\
>0.9\end{array}$ & $\begin{array}{l}\text { RMSEA } \\
<0.1\end{array}$ \\
\hline Model 3 & 137.4 & 4.17 & 0.95 & 0.93 & 0.95 & 0.08 \\
\hline Model 4 & 37.9 & 1.7 & 0.98 & 0.98 & 0.99 & 0.04 \\
\hline
\end{tabular}

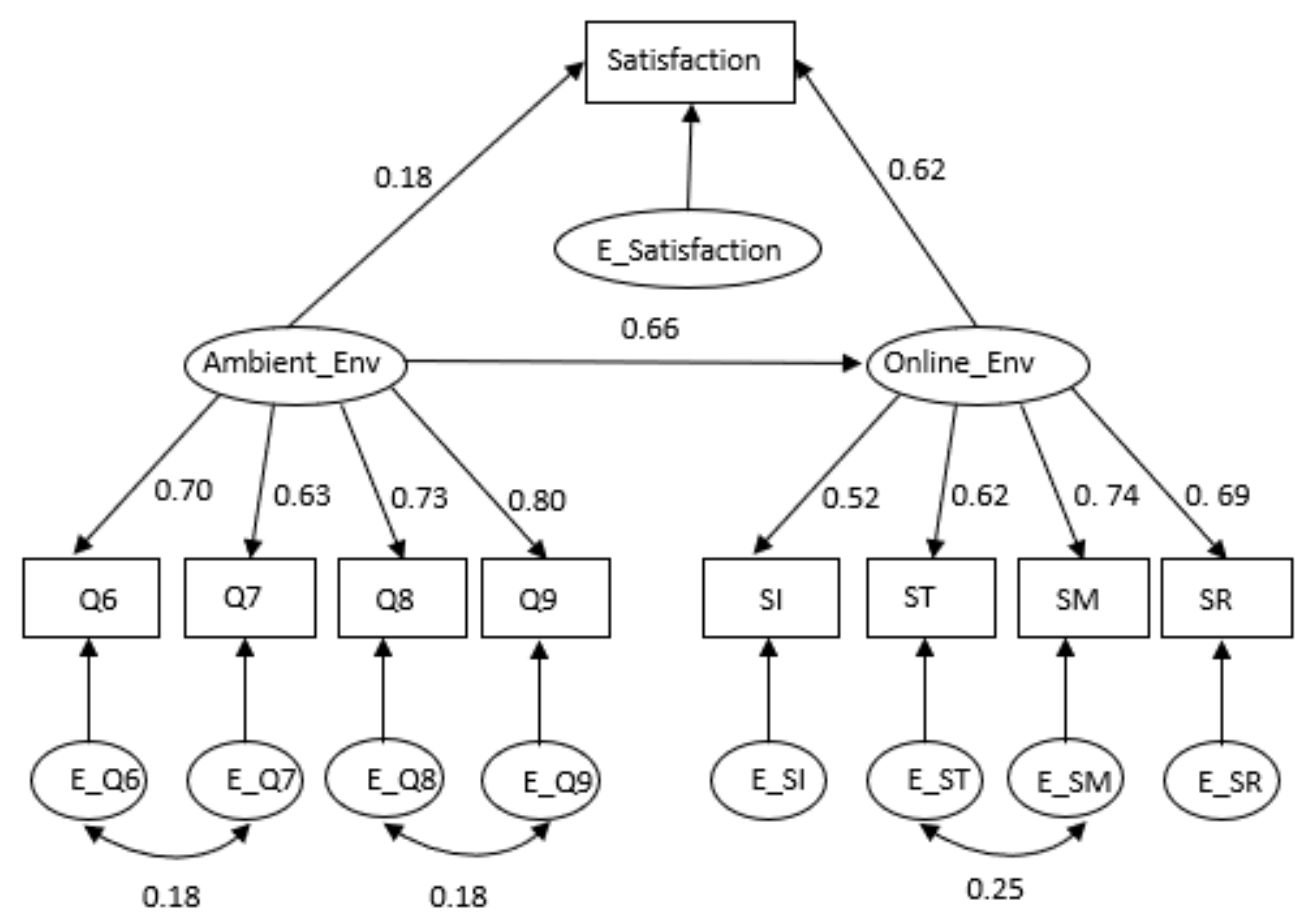

Fig 3: SEM Model with standardized estimates $(\mathrm{N}=523)$ 


\section{DISCUSSION}

The "Learning Environment Evaluation Questionnaire" is a survey instrument designed to understand students' perception of ambient and online environment and satisfaction with learning environment in online learning context. H1 was supported by the results from explorative factor analysis and confirmatory factor analysis, which identified and confirmed a six-factor structure of the 21 perception items. Six items did not have loadings more than 0.5 and were removed from the model. The fit of CFA model (Model 2) was good, with all paths statistically significant. The covariances improved the model fit. The six scales correlated with each other.

The purpose of the 21-item perceptions of learning environment measure was to gather the evidence of students' satisfaction on learning environment can be affected by perceived ambient learning environment and perceived online learning environment $(\mathrm{H} 2)$ which was supported by the structural equation modeling. The model (Model 4) has good fit according to goodness-of-fit indices, with all paths in the model statistically significant. Latent variable online environment has four sub-constructs: student-interface relationships, student-tutor relationships, studentcontent relationships, and student reflection activities. Student-student interaction which used to be included in OLLES is deleted from Model 4 because of not large enough loading value. It also makes sense as the form of online learning in this study is that students watching videos from the platform without much student-student interactions.

The lack of student-student interaction might influence students online learning experience. Student-student interaction were found to be significant contributors of student learning and satisfaction in a study of web-based online university programs (Sher, 2009). Researchers believes interaction is one of the most important factors in learning outcomes (Collison, Elbaum, Havind, \& Tinker, 2000). Different learning styles affect learners' interaction frequency. Sabry and Baldwin (2003) found sequential learners used student-information interaction and studentteacher interaction more frequently while global learners used student-student interaction more frequently. All this studies and theory point that interactions among peer students are significant in online learning process.

Another study asking students' the biggest challenges in online learning and what cannot be replaced from the physical classroom has been done to further understand students' learning experience and behavior. More than 30\% students think interaction is the biggest challenge in online learning. More students think interacting with peer students cannot be fulfilled by online learning platform than interacting with instructors. This result further supports the theory and studies on the importance on student-student interaction in online learning environment. Therefore, it would be necessary to provide students more opportunities to communicate with their peers in the online learning environment.

The scale of perceived comfort on ambient environment was positively associated with overall perceived satisfaction on learning environment with the coefficient of 0.18 . The scale of perceived satisfaction on online learning environment was positively associated with overall perceived satisfaction on learning environment with the coefficient of 0.62 . Perceived comfort on 
ambient environment was also positively associated with satisfaction on online learning environment with the coefficient of 0.66 .

Online learning is becoming a trend and accelerated by the COVID-19. The physical environment where online learning is taken however, has been ignored by researchers and educators. One of the reasons is the lack of instrument to systematically measure both physical learning environment and online learning environment. The development and field test of this tool will help fill this gap and support a systematical view on designing and managing learning environment. It can be used to evaluate particular online learning scenario, generate knowledge of students' satisfaction with both ambient learning environment and online leaning environment.

This paper is limited to consider the effect of physical learning environment only from ambient attributes. Another important attribute of physical learning environment- spatial attribute needs to be further studied. Also, this study was only conducted in four middle schools in Hangzhou, China. More evidence needs to be collected from other cases. 


\section{REFERENCES}

Clayton, J. F. (2007). Development and validation of an instrument for assessing online learning environments in tertiary education: The Online Learning Environment Survey (OLLES) (Doctoral dissertation, Curtin University).

Cunningham, H. V., \& Tabur, S. (2012). Learning Space Attributes: Reflections on Academic Library Design and Its Use. Journal of Learning Spaces, 1(2), n2.

Ellis R. Down with boring e-learning! Interview with e-learning guru Dr. Michael W. Allen. Learning circuits Retrieved from http://www.astd.org/LC/2004/0704_allen.htm (2004)

L. Triacca, D. Bolchini, L. Botturi, A. Inversini Mile: Systematic usability evaluation for eLearning web applications AACE Journal, 12 (4) (2004)

Lackney, J.A. (2000, November). Thirty-three educational design principles. Electronic paper found on the National Clearinghouse for Educational Facilities Website sponsored by the U.S. Department of Education, p. 30.

Lackney, J.A. (1999, September). Assessing school facilities for learning/assessing the impact of the physical environment on the educational process: Integrating theoretical issues with practical concerns. Newark, NJ: NJIT Conference. Retrieved November 12, 2002, from http://www/edi.msstate.edu

Lang, D. (1996). Essential criteria for an ideal learning environment. Center for Architecture and education. Retrieved November 15, 2002, from http://www/newhorizons.org

Moore, J. L., Dickson-Deane, C., \& Galyen, K. (2011). e-Learning, online learning, and distance learning environments: Are they the same?. The Internet and Higher Education, 14(2), 129-135.

M. Nichols A theory of eLearning Educational Technology \& Society, 6 (2) (2003), pp. 1-10

Papadotas, S.P. (1973). Color them motivated-Color's psychological effects on students.

Revelle, W., \& Revelle, M. W. (2015). Package 'psych'. The Comprehensive R Archive Network.

Rosseel, Y. (2012). Lavaan: An R package for structural equation modeling and more. Version 0.5-12 (BETA). Journal of statistical software, 48(2), 1-36.

T. Newby, D. Stepich, J. Lehman, J. Russell (2000). Instructional technology for teaching and learning: Designing instruction, integrating computers, and using media (2nd ed.), Prentice-Hall, Columbus, $\mathrm{OH}$

Safer, A.M., Farmer, L.S.J., Segalla, A., \& Elhoubi, A.F. (2005). Does the distance from the teacher influence student evaluations? Educational Research Quarterly, 28(3), 28-35.

Jesus, Â., Cruz, A., \& Gomes, M. J. (2011). Online learning environment surveys for higher education: Comparative analysis and future research.

Sher, A. (2009). Assessing the relationship of student-instructor and student-student interaction to student learning and satisfaction in web-based online learning environment. Journal of Interactive Online Learning, 8(2).

Sabry, K., \& Baldwin, L. (2003). Web-based learning interaction and learning styles. British Journal of Educational Technology, 34(4), 443-454. 